\title{
Isolation and Genotyping of Toxoplasma gondii Strains in Ovine Aborted Fetuses in Khorasan Razavi Province, Iran
}

\author{
Leila Danehchin', Gholamreza Razmi1 ${ }^{1,2 *}$, Abolghasem Naghibi' \\ ${ }^{1}$ Department of Pathobiology and ${ }^{2}$ Center of Excellence in Ruminant Abortion and Neonatal Mortality, Faculty of Veterinary Medicine, Ferdowsi \\ University of Mashhad, Mashhad, Iran
}

\begin{abstract}
Toxoplasmosis is an important zoonotic disease that can cause abortion in humans and animals. The aim of this study was isolation and subsequent genotyping of Toxoplasma gondii isolates in ovine aborted fetuses. During 20122013, 39 ovine aborted fetuses were collected from sheep flocks in Khorasan Razavi Province, Iran. The brain samples were screened for detection of the parasite DNA by nested PCR. The positive brain samples were bioassayed in Webster Swiss mice. The serum samples of mice were examined for T. gondii antibodies by IFAT at 6 weeks post inoculation, and $T$. gondii cysts were searched in brain tissue samples of seropositive mice. The positive samples were genotyped by using a PCR-RLFP method. Subsequently, GRA6 sequences of isolates were analyzed using a phylogenetic method. The results revealed that T. gondii DNA was detected in 54\% (20/37, 95\% Cl 38.4-69.0\%) brain samples of ovine aborted fetuses. In bioassay of mice, only 2 samples were virulent and the mice were killed at 30 days post inoculation, while the others were non-virulent to mice. The size of cysts ranged 7-22 $\mu \mathrm{m}$. Complete genotyping data for GRA6 locus were observed in 5 of the 20 samples. PCR-RLFP results and phylogenetic analysis revealed that all of the isolated samples were closely related to type I. For the first time, we could genotype and report $T$. gondii isolates from ovine aborted fetuses in Khorasan Razavi Province, Iran. The results indicate that the T. gondii isolates are genetically related to type I, although most of them were non-virulent for mice.
\end{abstract}

Key words: Toxoplasma, PCR-RFLP, aborted fetus, genotyping, sheep, Iran

\section{INTRODUCTION}

Toxoplasma gondii is an intercallular protozoan that infects humans and animals. Sheep can be infected by ingesting oocysts excreted in cats' feces and transplacental transfer [1]. Infection with T. gondii can lead to abortion, stillbirth, and birth of weak lamb in sheep flock [2,3]. Toxoplasma strains have been categorized into 3 clonal lineages (I, II, and III) according to virulence in outbreed mice. Previous studies have proved that the type I strains are lethal to mice, whereas experimental infection of mice with type II or III strains represented low virulence [4]. Recently, several molecular techniques such as multilocus enzyme electrophoresis [5], PCR-RFLP [6,7], microsatellite method $[8,9]$, and multilocus DNA sequencing [10] have been used for T. gondii genotyping. In most genotyping studies,

\footnotetext{
- Received 3 October 2015, revised 30 November 2015, accepted 9 December 2015. *Corresponding author (razmi@um.ac.ir) (c) 2016, Korean Society for Parasitology and Tropical Medicine This is an Open Access article distributed under the terms of the Creative Commons Attribution Non-Commercial License (http://creativecommons.org/licenses/by-nc/3.0) which permits unrestricted non-commercial use, distribution, and reproduction in any medium, provided the original work is properly cited.
}

multiple genetic markers were analyzed by using multilocus PCR-RFLP and microsatellite methods $[6,8]$, although these methods do not always provide satisfactory results due to insufficient amounts of extracted parasite DNA. Among different markers, GRA6 gene is a single copy gene and more polymorphic than the others markers and could clearly differentiate 3 different genotypes (I, II, and III) by using a single PCR reaction followed by single endonuclease (MseI) digestion [11].

Many studies have been done about genotyping of T. gondii in humans and animals around the world. The population structure of Toxoplasma has been analyzed with a variety of molecular probes. The results have shown that the number of T. gondii types is more than the classical types, and some strains have been categorized under atypical types $[11,12]$. Available data about T. gondii genotypes of ovine aborted fetuses is limited. So far, the type II, III, and atypical ones have been reported in aborted and healthy sheep from UK, Denmark, France, USA, Brazil, Italy, and Ethiopia [13-21].

In Iran, the overall prevalence of Toxoplasma infection was estimated to be $31 \%$ in sheep [22], and a few studies have been reported about genotyping of $T$. gondii in sheep. The type II and 
III have been identified in adult sheep using GRA6 locus along with 5 satellite markers [23]. The type I was found in ovine aborted fetuses using BI gene as a marker [24]. So far, Toxoplas$m a$ infection has been recognized as an important causative abortion in sheep flocks of Khorasan Razavi Province, Iran $[25,26]$. The aim of this study was to isolate and identify T. gondii genotypes in ovine aborted fetuses in the province.

\section{MATERIALS AND METHODS}

\section{Study field}

Khorasan Razavi Province is located in northeastern Iran $\left(33^{\circ} 30^{\prime}-37^{\circ} 41^{\prime} \mathrm{N} ; 56^{\circ} 19^{\prime}-61^{\circ} 18^{\prime} \mathrm{E}\right)$, with an area $>127,000$ $\mathrm{km}^{2}$. The northern part of the province is mountainous and has suitable conditions for agricultural activity and animal husbandry, while the southern part is mostly semi-desert and desert, with poor vegetation cover.

\section{Sample collection}

From 2012 to 2013, 39 aborted ovine fetuses were collected from different areas of the province. First, the fetuses and fetal membranes were grossly examined for any macroscopic lesions, and the age of aborted fetuses was also determined by crownrump length [27]. Then, the fetuses were necropsied to collect the brain tissue for molecular and bioassay examinations.

\section{DNA extraction and PCR}

Genomic DNA was extracted from samples using MBST Genomic DNA kit (Institute of Molecular and Biological Transmission Systems, Tehran, Iran) as per manufacturer's recommendations. Subsequently, a nested PCR assay was carried out to detect the T. gondii B1 gene as previously described by Burg et al. [28].

\section{Bioassay in mice}

A $100 \mathrm{~g}$ of brains of positive aborted fetuses was homogenized in $500 \mathrm{ml}$ of aqueous $0.85 \% \mathrm{NaCl}$ solution (saline) with antibiotics (100 IU/ml penicillin and $745 \mathrm{IU} / \mathrm{ml}$ streptomycin) and then homogenized by electrical mixture. At the end, it was passed through 2 layers of gauze. After $3 \mathrm{hr}$ incubation at room temperature, the samples were centrifuged at 1,500 g for $5 \mathrm{~min}$, and $3 \mathrm{ml}$ of the homogenate deposit was administrated subcutaneously to 3 Swiss Webster mice ( $1 \mathrm{ml}$ per each mouse). At 6 weeks post inoculation, blood samples were taken from tail of mice, and 1:16 dilution of serum was tested to detect T. gondii antibodies by IFAT [29]. Seropositive mice were sacrificed at 42 days post infection by chloroform-inhalation. For detection of cysts, brain impression smears were prepared and microscopically examined. The inoculated mice were considered as infected when the mice had antibody titers $\geq 10$ against Toxoplasma infection, or tissue cysts were found in the brain.

\section{Genotyping of T. gondii}

T. gondii DNA was extracted from the brain of infected mice, and genotyping was performed by PCR-RFLP with GRA6 marker as described previously [30]. Briefly, the PCR reaction was performed in a $25 \mu \mathrm{l}$ reaction mixture containing $10 \mathrm{pmol}$ of each primer (forward primer, 5'-GTAGCGTGCTTGTTGGCGAC-3', and reverse primer, 5'-ACAAGACATAGAGTGCCCC-3') and $10 \mu \mathrm{l}$ of extracted DNA, $75 \mathrm{mM}$ Tris-HCl (pH 8.5), $20 \mathrm{mM}\left(\mathrm{NH}_{4}\right)_{2} \mathrm{SO}_{4}, 1.5 \mathrm{mM} \mathrm{MgCl}_{2}, 0.1 \%$ Tween $20,0.2$ $\mathrm{mM}$ dNTPs, $0.025 \mathrm{U} / \mu \mathrm{l}$ amplicon Taq DNA polymerase, inert red dye, and a stabilizer. The PCR conditions were $5 \mathrm{~min}$ at $95^{\circ} \mathrm{C}$ followed by 35 cycles of $30 \mathrm{sec}$ at $94^{\circ} \mathrm{C}, 1 \mathrm{~min}$ at $60^{\circ} \mathrm{C}, 2$ min at $72^{\circ} \mathrm{C}$, and a final elongation of $72^{\circ} \mathrm{C}$ for $7 \mathrm{~min}$. The PCR products were separated on a $1.5 \%$ agarose gel with $1 \times \mathrm{TAE}$ buffer and visualized by staining with ethidium bromide. The GRA6 amplification product was exposed to Msel enzyme for digestion. Briefly, 15-ml of PCR product was digested using 1.5 $\mathrm{U}$ of Msel endonuclease and $2 \mathrm{U}$ buffer $\mathrm{R}$ and incubated at $65^{\circ} \mathrm{C}$ for $4 \mathrm{hr}$ in accordance with the manufacturer's protocol. The restriction fragments were separated by electrophoresis in $1.6 \%$ agarose gel followed by staining with ethidium bromide and visualization under UV. The cut position of MseI in GRA6 genes of types I, II, and III was 168 bp and 712 bp, 71 bp and 694 bp, and 71 bp, 168 bp, and 712 bp, respectively [30].

\section{Gene sequencing and phylogeny}

The PCR products purified and sequenced in the facilities of Bioneer Inc. (Seoul, Korea). The primers, which were previously used for PCR product of GRA6, were applied for the sequencing reactions. The nucleotide sequences were assembled and edited using CLC bio software. They were aligned with nucleotide sequences of GRA6 genes of different references T. gondii strains using ClustalW method. The phylogenetic analysis was carried out using neighbor-joining analysis with bootstrap values of 1,000 replicates (Programme Mega software version 6).

\section{Ethics and animal experimentation}

The mice were housed and maintained in the animal care facility at Ferdowsi University of Mashhad, Iran. All animal ex- 
periments were performed in strict accordance with the guidelines approved by the Animal Ethics Committee of our faculty.

\section{RESULTS}

The brain samples of 37 ovine aborted fetuses were examined by semi-nested-PCR, and T. gondii DNA was detected in $54 \%$ of the brain samples (Fig. 1). The positive samples were bioassayed in mice during the experimental study, and 15\% of mice (9/60, 95\% CI 8.2-26.2\%) died between 18-30 days post infection. The sera of live animals were examined at 6 weeks post infection using IFAT, and 55\% of mice (33/60, 95\% CI 42.5$66.9 \%$ ) resulted positive for the T. gondii antibody assay. Tissue

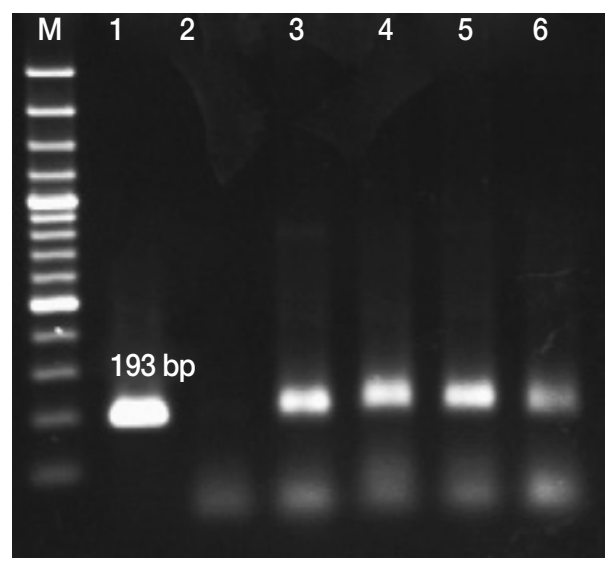

Fig. 1. PCR amplification products of Toxoplasma gondii B1 in aborted fetuses brain samples Lane $\mathrm{M}$, molecular weight marker (between 1,000 and 50 bp); 1, positive control (Toxoplasma tachyzoites); 2, negative control $\left(\mathrm{H}_{2} \mathrm{O}\right.$ instead of DNA); 3-6, positive samples.

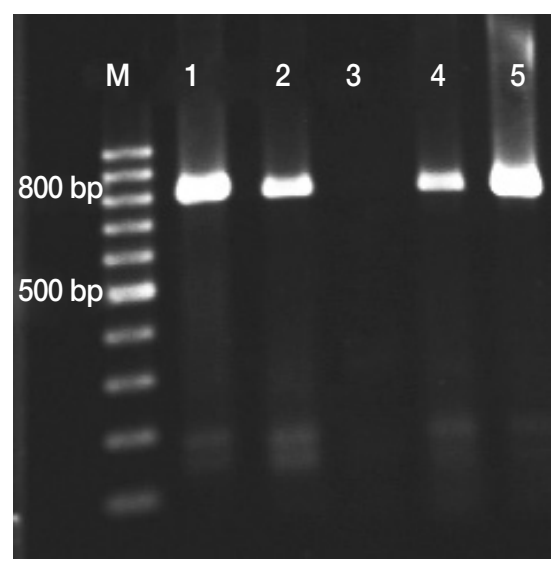

Fig. 2. PCR amplification products of Toxoplasma gondii GRA6 in mice brain samples. Lane $\mathrm{M}$, molecular weight marker (between 1,000 and 100 bp); 1-2, positive control (Toxoplasma tachyzoites); 3, negative control ( $\mathrm{H}_{2} \mathrm{O}$ instead of DNA); 4-5, positive samples. cysts of $T$. gondii were identified in brain tissues of inoculated mice by direct microscopy. The size of cysts ranged 7-22 $\mu \mathrm{m}$.

The brain samples of mice were analyzed by GRA6 PCR method. Totally, complete genotyping data for GRA6 locus were observed just in 5 isolates (Fig. 2). In order to detect the genotype of Toxoplasma samples, GRA6 products were digested with MseI restriction enzyme, and the type of samples was determined by digestion patterns. All positive DNA fragments

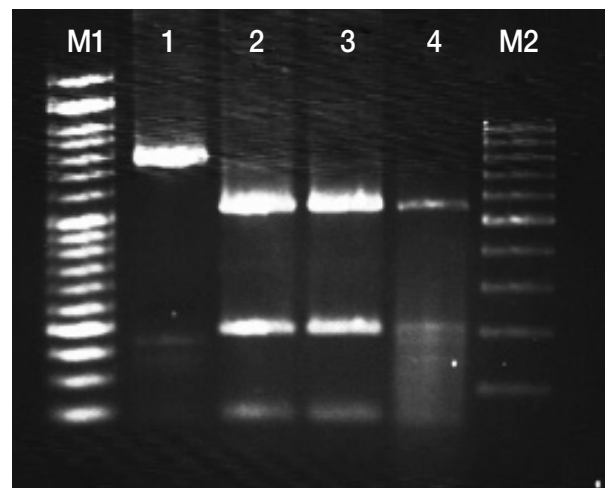

Fig. 3. PCR-RFLP analysis of GRA6 gene coding region with Msel endonuclease. Lanes M1 and M2 are DNA size markers (between 1,000 and 100 bp). Lane 1, undigested PCR products of GRA6 gene; 2-4, digested PCR products of GRA6 gene for Type 1.

Table 1. Results of Bioassay and genotyping of Toxoplasma gondii isolated from ovine aborted fetuses which were T. gondii DNA positive cases by nested PCR

\begin{tabular}{|c|c|c|c|c|c|}
\hline $\begin{array}{l}\text { Aborted } \\
\text { fetuses } \\
\text { no. }\end{array}$ & $\begin{array}{l}\text { Organ for } \\
\text { bioassay }\end{array}$ & $\begin{array}{c}\text { No. of } \\
\text { seropositive } \\
\text { mice/No. of } \\
\text { inoculated mice }\end{array}$ & $\begin{array}{l}\text { No. of } \\
\text { dead } \\
\text { mice }\end{array}$ & $\begin{array}{c}\text { Day of } \\
\text { death } \\
\text { (day) }\end{array}$ & $\begin{array}{l}\text { Genotyping by } \\
\text { GRA6 marker }\end{array}$ \\
\hline 1 & Brain & $3 / 3$ & 3 & 30 & Type I \\
\hline 2 & Brain & $2 / 3$ & 3 & 30 & Type I \\
\hline 3 & Brain & $2 / 3$ & 0 & 42 & Type I \\
\hline 4 & Brain & $1 / 3$ & 0 & 42 & Type I \\
\hline 5 & Brain & $2 / 3$ & 0 & 42 & \\
\hline 6 & Brain & $1 / 3$ & 2 & 25 & \\
\hline 7 & Brain & $1 / 3$ & 0 & 42 & \\
\hline 8 & Brain & $2 / 3$ & 0 & 42 & \\
\hline 9 & Brain & $2 / 3$ & 1 & 18 & \\
\hline 10 & Brain & $1 / 3$ & 0 & 42 & \\
\hline 11 & Brain & $1 / 3$ & 0 & 42 & \\
\hline 12 & Brain & $1 / 3$ & 0 & 42 & \\
\hline 13 & Brain & $1 / 3$ & 0 & 42 & \\
\hline 14 & Brain & $2 / 3$ & 0 & 42 & \\
\hline 15 & Brain & $2 / 3$ & 0 & 42 & Type I \\
\hline 16 & Brain & $2 / 3$ & 0 & 42 & \\
\hline 17 & Brain & $1 / 3$ & 0 & 42 & \\
\hline 18 & Brain & $2 / 3$ & 0 & 42 & \\
\hline 19 & Brain & $2 / 3$ & 0 & 42 & \\
\hline 20 & Brain & $2 / 3$ & 0 & 42 & \\
\hline
\end{tabular}


Table 2. Comparison of nucleotide sequences of GRA6 gene coding of $T$. gondii isolates from Mashhad area, Iran with reference strains

\begin{tabular}{|c|c|c|c|c|c|c|c|c|c|c|c|c|c|c|c|c|c|c|c|}
\hline \multirow{2}{*}{ Strains } & \multicolumn{19}{|c|}{ Positions of variable nucleotides } \\
\hline & 41 & 71 & 106 & 162 & 171 & 195 & 304 & 336 & 561 & 575 & 576 & 614 & 638 & 654 & 677 & 687 & 690 & 692 & 702 \\
\hline $\mathrm{RH}$ & C & $G$ & C & G & A & $\mathrm{C}$ & $A$ & $\mathrm{~T}$ & A & $G$ & A & $G$ & $G$ & A & C & C & A & C & $\mathrm{T}$ \\
\hline GT1 & * & * & * & * & * & * & * & * & * & * & * & * & * & * & * & * & * & * & * \\
\hline Tg shir1 & * & * & * & * & * & * & * & * & * & * & * & * & * & * & * & * & * & * & * \\
\hline Tg shir2 & * & * & * & * & * & * & * & * & * & * & * & * & - & - & - & - & - & - & - \\
\hline M 7741 & * & * & * & * & * & * & * & * & * & * & * & C & * & * & * & $T$ & * & * & C \\
\hline RUB & * & $T$ & * & * & * & $T$ & $T$ & * & C & C & * & * & * & * & * & * & * & * & * \\
\hline CASSTTLE & * & $\mathrm{T}$ & * & A & * & * & $\mathrm{T}$ & * & C & * & * & * & A & * & * & * & G & A & * \\
\hline C56 & * & $\mathrm{T}$ & $\mathrm{T}$ & A & * & * & $\mathrm{T}$ & * & C & * & * & C & * & * & * & * & * & * & * \\
\hline NED & * & $\mathrm{T}$ & $\mathrm{T}$ & A & * & * & $\mathrm{T}$ & * & C & * & * & C & * & * & * & * & * & * & * \\
\hline ME49 & $\mathrm{T}$ & $\mathrm{T}$ & * & * & $G$ & * & $\mathrm{T}$ & C & * & * & * & * & * & * & * & * & $G$ & A & A \\
\hline BEVERLEY & $\mathrm{T}$ & $\mathrm{T}$ & * & * & $G$ & * & $\mathrm{T}$ & C & * & * & $G$ & * & - & $A$ & C & * & $G$ & A & A \\
\hline
\end{tabular}

Asterisk (*) indicates the same nucleotides of the sequence of $\mathrm{RH}$, and Dashes (-) indicates deletion sites.

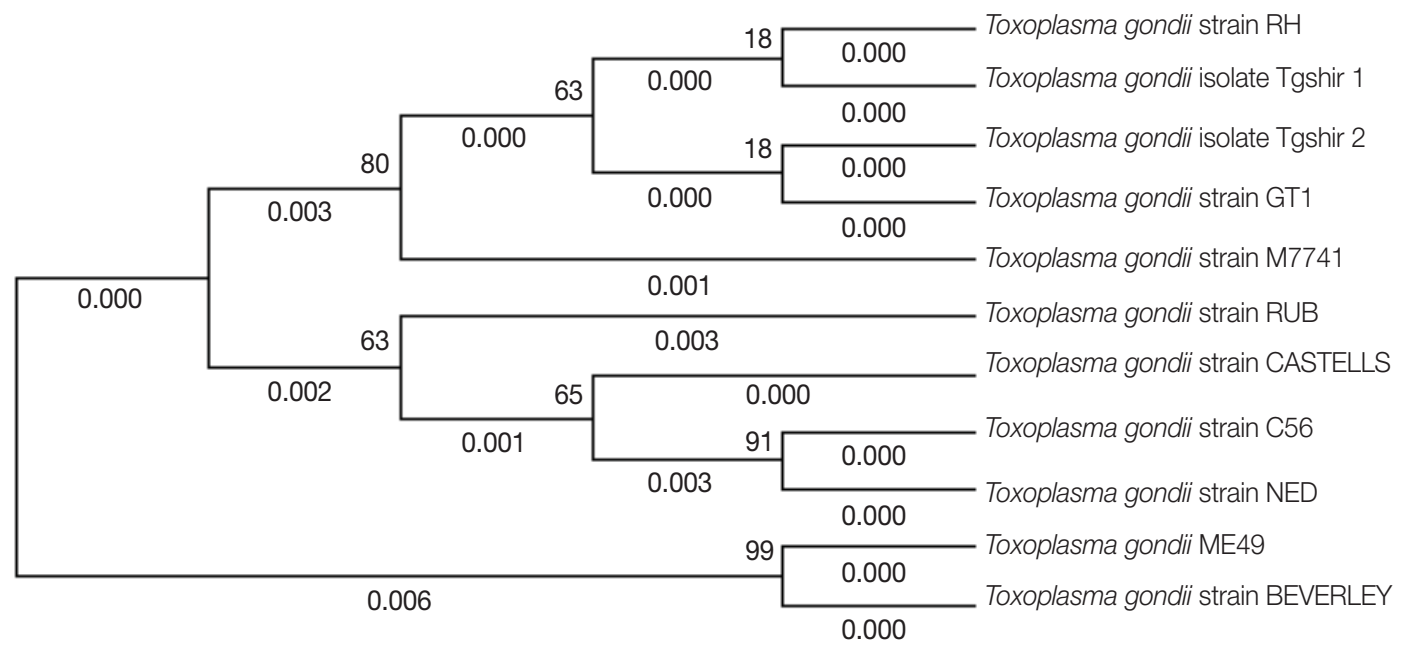

Fig. 4. Phylogenetic analysis of representative Iran isolates (Tgshir1,Tgshir2) and reference strains; Strain RH (Type I), GTI (Type I), ME 49 (type II), M7741 (type III), NED (type III), Beverley (type III), RUB (Atypical), C56 (Atypical), and CASTELLE (Atypical). The tree was constructed using the neighbor-joining method after bootstrapping with 1,000 repetitions.

had 2 cut sites for Msel restriction enzyme, as the digestion pattern of type I (Fig. 3). Detailed information concerning the samples has been summarized in Table 1. The amplified GRA6 genes of the 6 isolates were sequenced and deposited in GenBank (NCBI) under the accession nos. of KM372587 (TgShir 1) and KM372588 (TgShir 2). The nucleotide sequences of GRA6 gene from isolates were aligned with nucleotide sequences of T. gondii (Table 2). The sequenced PCR products were found to have $99 \%$ homology with the analysis. The sequence homologies in the neighbor-joining analysis of strains isolated from ovine aborted fetuses and references strains of $T$. gondii showed that all of the isolates were clustered in type I strain (Table 2; Fig. 4).

\section{DISCUSSION}

In this study, T. gondii DNA was detected in 54\% of brain samples of aborted fetuses in sheep. T. gondii infection has been detected in sheep aborted fetuses to range between $13.5 \%$ to $61 \%$ in different areas of Iran by PCR assays $[24,26,31]$. The bioassayed results showed that $15 \%$ of inoculated mice died before 30 days, and the other inoculated mice (85\%) developed antibodies against $T$. gondii and survived until sacrificed time, thus indicating that the majority of isolates belong to avirulent strain. In the previous study, an avirulent strain was isolated from aborted ovine fetuses in Iran by bioassay method [25]. The results of other studies indicated that most of the T. gondii 
isolates from sheep were non-virulent for mice $[15,16,18,21]$. In the present study, the tissue cysts with small size $(7-22 \mu \mathrm{m})$ were observed in the brain of inoculated mice at 6 weeks post infection. The size of Toxoplasma tissue cysts is depending on the age of the cyst. The young tissue cysts may be small and contain only 2 bradyzoites while older ones may contain hundreds of organisms; tissue cysts in the brain are often spherical and reach a diameter of $70 \mathrm{~mm}[32,33]$.

The PCR-RFLP based on GRA6 revealed that all isolates in this study from ovine aborted fetuses belong to type I clonal lineage. This result is in agreement with a previous study that type I was also detected in 12 sheep aborted fetuses in Iran using B1 gene as a target sequence for PCR-RLFP [24]. In another study, type II and III were reported in 4 isolates from adult sheep according to microsatellite and GRA6 gene sequence analysis in Iran [23]. In other countries, Owen and Trees [13] detected type II using PCR assays based on the SAG2 locus in the placentas of 13 aborted sheep from UK. Likewise, Jungersen et al. [14] showed that 11 (6 from aborted lambs, 5 from healthy sheep) isolates of T. gondii from Denmark were type II. Similarly, another study using the SAG2 locus and 5 satellite markers (TUB2, TgM-A, W35, B17, and B18) proved that all 8 T. gondii isolates derived from adult sheep in France were clonal type II [15].

Interestingly, during a study on 10 PCR-RFLP markers, 47 of 57 T. gondii isolates in USA were type II or III, while the remaining isolates were reported as atypical [16]. Moreover, they could isolate an atypical strain by using same markers in a flock of purebred Suffolk ewes on a farm in Texas [17]. Recently, a study has been performed on aborted ovine fetuses on Sardinia Island, Italy. They indicated that all isolates were type II by using 11 markers [20]. According PCR-RLFP of the GRA6 gene, the type I, II, and III of Toxoplasma were reported from pigs in Japan [34], the type II and III from humans, chicken, duck, and cat in Iran [23] and type II and III from humans in Cyprus [35].

In the present study, the GRA6 sequencing and phylogenetic analysis confirmed that our 2 isolates were closely related to type I (RH and GTI strains). Although the coding region of the GRA6 locus is a considerably polymorphic target and more variable than the other markers examined, it could clearly differentiate the 3 different genotypes (I, II, and III) by using a single PCR reaction [30]. However, recent studies have shown that the high genetic diversity among T. gondii isolates in livestock and typing of T. gondii isolates using 1 molecular marker is not so reliable to detect atypical strains from type III and I $[7,9,10]$. On the other hand, in the classic genotyping of T. gondii, type I isolates were virulent with high mortality in mice [1], while in the present study, only $10 \%$ of $T$. gondii isolates were virulent for mice. Therefore, it seems that the report of type I from ovine aborted fetuses is questionable and need more investigation.

In conclusion, T. gondii DNA was detected in the brain samples of ovine aborted fetuses. Our results showed that T. gondii isolates were closely related to the type I, whereas the results pathogenically indicated significant differences in mice. We suggest examining more molecular markers for identification of unknown strains to obtain more credible results. Prospectively, determining the predominant type of T. gondii in endemic areas such as Khorasan Province could pave the way for control, prevention, and development of an effective vaccine.

\section{ACKNOWLEDGMENTS}

We are very grateful to Drs. Zahra Naseri, H. Eshrati, and G. A. Azari for their technical assistance. This study was supported by a grant no. VPRTFM-3.27748 from the Vice President Research and Technology of Ferdowsi University of Mashhad, Iran.

\section{CONFLICT OF INTEREST}

The authors declare that they have no conflict of interest.

\section{REFERENCES}

1. Dubey JP. Toxoplasmosis of Animals and Humans, 2nd ed. Boca Raton, Florida, USA. CRC Press. 2010, pp. 1-14.

2. Buxton D, Maley SW, Wright SE, Rodger S, Bartley P, Innes EA. Toxoplasma gondii and ovine toxoplasmosis: new aspects of an old story. Vet Parasitol 2007; 149: 25-28.

3. Dubey JP. Toxoplasmosis in sheep-the last 20 years. Vet Parasitol 2009; 163: 1-14.

4. Sibley LD, Boothroyd JC. Virulent strains of Toxoplasma gondii comprise a single clonal lineage. Nature 1992; 359: 82-85.

5. Darde ML, Bouteille $B$, Pestre-Alexandre M. Isoenzyme analysis of 35 Toxoplasma gondii isolates and the biological and epidemiological implications. J Parasitol 1992; 78: 786-794.

6. Su C, Zhang X, Dubey JP. Genotyping of Toxoplasma gondii by multilocus PCR-RFLP markers: a high resolution and simple method for identification of parasites. Int J Parasitol 2006; 36: 841-848.

7. Su C, Shwab E K, Zhou P, Zhu XQ, Dubey JP. Moving towards an integrated approach to molecular detection and identification of Toxoplasma gondii. Parasitology 2010; 137: 1-11

8. Ajzenberg D, Bañuls AL, Tibayrenc M, Dardé ML. Microsatellite 
analysis of Toxoplasma gondii shows considerable polymorphism structured into two main clonal groups. Int J Parasitol 2002; 32: 27-38.

9. Ajzenberg D, Collinet F, Mercier A, Vignoles P, Dardé ML. Genotyping of Toxoplasma gondii isolates with 15 microsatellite markers in a single multiplex PCR assay. J Clin Microbiol 2010; 48 : 4641-4645.

10. Khan A, Dubey JB, Su C, Ajioka JW, Rosenthal BM, Sibley LD. Genetic analyses of atypical Toxoplasma gondii strains reveal a fourth clonal lineage in North America. Int J Parasitol 2011; 41:645-655.

11. Darde ML, AJzenberg D, Su S. Molecular epidemiology and population structure of Toxoplasma gondii. In Weiss LM, Kim K eds, Toxoplasma gondii The Model Apicomplexan-Perspectives and Methods. 2nd ed. Amesterdam, The Netherlands. Elsevier. 2014, pp. 66-93.

12. Darde ML. Biodiversity in Toxoplasma gondii. Curr Top Microbiol Immunol 1996; 219: 27-41.

13. Owen MR, Trees AJ. Genotyping of Toxoplasma gondii associated with abortion in sheep. J Parasitol 1999; 85: 382-384.

14. Jungersen G, Jensen L, Rask MR, Lind P. Non-lethal infection parameters in mice separate sheep type II Toxoplasma gondii isolates by virulence. Comp Immunol Microbiol Infect Dis 2002; 25: 187-195.

15. Dumètre A, Ajzenberg D, Rozette L, Mercier A, Dardé ML. Toxoplasma gondii infection in sheep from Haute-Vienne, France: seroprevalence and isolate genotyping by microsatellite analysis. Vet Parasitol 2006; 142: 376-379.

16. Dubey JP, Sundar N, Hill D, Velmurugan GV, Bandini LA, Kwok OC, Majumdar D, Su C. High prevalence and abundant atypical genotypes of Toxoplasma gondii isolated from lambs destined for human consumption in the USA. Int J Parasitol 2008; 38: 9991006.

17. Edwards JF, Dubey JP. Toxoplasma gondii abortion storm in sheep on a Texas farm and isolation of mouse virulent atypical genotype T. gondii from an aborted lamb from a chronically infected ewe. Vet Parasitol 2013; 192: 129-136.

18. Ragozo, AM, Pena HF, Yai LE, Su C, Gennari SM. Genetic diversity among Toxoplasma gondii isolates of small ruminants from Brazil: novel genotypes revealed. Vet Parasitol 2010; 170: 307312.

19. Da Silva RC, Langoni H, Su C, Da Silva AV. Genotypic characterization of Toxoplasma gondii in sheep from Brazilian slaughterhouses: new atypical genotypes and the clonal type II strain identified. Vet Parasitol 2011; 175: 173-177.

20. Chessa G, Chisu V, Porcu R, Masala G. Molecular characterization of Toxoplasma gondii Type II in sheep abortion in Sardinia, Italy. Parasite 2014; 21: 6.

21. Gebremedhin EZ, Abdurahaman M, Tessema TS, Tilahun G, Cox E, Goddeeris B, Dorny P, De Craeye S, Dardé ML, Ajzenberg D. Isolation and genotyping of viable Toxoplasma gondii from sheep and goats in Ethiopia destined for human consumption. Parasit Vectors 2014; 4: 425.
22. Sharifi M, Sarvi Sh, Shokri A, Hosseini-Teshnizi S, Rahimi MT, Mizani, A, Ahmadpour E, Daryani A. Toxoplasma gondii infection among sheep and goats in Iran: a systematic review and metaanalysis. Parasitol Res 2015; 114: 1-16.

23. Zia-Ali N, Fazaeli A, Khoramizadeh M, Ajzenberg D, Dardé M, Keshavarz-Valian H. Isolation and molecular characterization of Toxoplasma gondii strains from different hosts in Iran. Parasitol Res 2007; 101: 111-115.

24. Habibi GR, Imani AR, Gholami MR, Hablolvarid MH, Behroozikhah AM, Lotfi M, Kamalzade M, Najjar E, Esmaeil-Nia K, Bozorgi S. Detection and identification of Toxoplasma gondii type I infection in sheep aborted fetuses in Qazvin Province of Iran. Iran J Parasitol 2012; 7: 64-72.

25. Razmi GR, Ghezi K, Mahooti A, Naseri Z. A serological study and subsequent isolation of Toxoplasma gondii from aborted ovine fetuses in Mashhad area, Iran. J Parasitol 2010; 96: 812814.

26. Rassouli M, Razmi GR, Basami M, Movassaghi AR, Azizzadeh M. Study on ovine abortion associated with Toxoplasma gondii in affected herds of Khorasan Razavi Province, Iran based on PCR detection of fetal brains and maternal serology. Parasitology 2011; 138: 691-697.

27. Evans HE, Sack WO. Prenatal development of domestic and laboratory mammals: growth curves, external features and selected refrences. Anat Histol Embryo 1973; 12: 11-45

28. Burg JL, Grover CM, Pouletty P, Boothroyd JC. Direct and sensitive detection of a pathogenic protozoan, Toxoplasma gondii, by polymerase chain reaction. J Clin Microbiol 1989; 27: 1787-1792.

29. Razmi GR, Rahbari S. Comparative study of three tests (modified direct agglutination test, indirect immunofluorescent antibody test and dye test) for detection of antibodies to Toxoplasma gondii in sheep sera. Iran J Vet Res 2001; 1: 12-19.

30. Fazaeli A, Carter PE, Dardé ML, Pennington TH. Molecular typing of Toxoplasma gondii strains by GRA6 gene sequence analysis. Int J Parasitol 2000; 30: 637-642.

31. Moazeni Jula F, Moazeni Jula G, Nozarian N, Hashemzadeh F. A serological and molecular study on Toxoplasma gondii in sheep and goats in Tabriz. Arch Razi Inst 2013; 68: 29-35.

32. Dubey JP, Lindsay DS, Speer CA. Structures of Toxoplasma gondii tachyzoites, bradyzoites, and sporozoites and biology and development of tissue cysts. Clin Microbiol Rev 1998; 11: 267-299.

33. Hooshyar H, Rostamkhani P, Arbabi M. Study on growth of Toxoplasma gondii tissue cyst in laboratory mouse. Jundishapur J Microbiol 2009; 2: 140-143.

34. Messaritakis I, Detsika M, Koliou M, Sifakis S, Antoniou M. Prevalent genotypes of Toxoplasma gondii in pregnant women and patients from Crete and Cyprus. Am J Trop Med Hyg 2008; 2: 205-209.

35. Zakimi S, Kyan H, Oshiro M, Sugimoto C, Xuenan X, Fujisaki K. Genetic characterization of GRA6 genes from Toxoplasma gondii from pigs in Okinawa, Japan. J Vet Med Sci 2006; 68: 1105-1107. 